\title{
PHYTOCHEMISTRY, PHARMACOLOGY AND ETHNOMEDICINAL USES OF FICUS THONNINGII (BLUME MORACEAE): A REVIEW
}

\section{${ }^{*}$ Rachael Dangarembizi ${ }^{1,2}$, Kennedy H. Erlwanger ${ }^{1}$, Davison Moyo ${ }^{1}$ and Eliton Chivandi ${ }^{1}$}

${ }^{1}$ School of Physiology, Faculty of Health Sciences, University of the Witwatersrand, 7 York Road, Parktown, Johannesburg, Republic of South Africa, ${ }^{2}$ Faculty of Medicine, National University of Science and Technology, Box AC939, Ascot, Bulawayo, Zimbabwe

*Email: rachaeldangarembizi@gmail.com

\begin{abstract}
The common wild fig, Ficus thonningii, is extensively used in African ethnomedicine for treating a number of disease conditions which include diarrhoea, urinary tract infections, diabetes mellitus, gonorrhoea, respiratory infections, and mental illnesses. This review aims to present a logical analysis of the nutritional, phytochemical and pharmacological properties of $F$. thonningii in relation to its therapeutic applications. A bibliographic analysis of the uses, phytochemical constituents and phytophamacological properties of Ficus thonningii was carried out using published papers, medicinal plant databases and various ethnobotanical and ethnopharmacological books. Ficus thonningii contains various bioactive compounds which include alkaloids, terpenoids, flavonoids, tannins and active proteins, all of which contribute to its curative properties. In vitro and in vivo pharmacological studies revealed that $F$. thonningii possesses antimicrobial, antidiarrhoeal, antihelmintic, antioxidant, anti-inflammatory and analgesic properties. Acute and sub-chronic toxicity studies have shown that Ficus thonningii is non-toxic if administered orally in low doses. Scientific research has validated the ethnomedicinal claims that Ficus thonningii is useful in disease management. However, there is need to continue identifying, isolating and quantifying the active principles and possibly determine the mechanisms underlying its curative properties.
\end{abstract}

Keywords: Ficus thonningii, phytochemical, toxicity, nutraceutical

\section{Introduction}

Plant-based remedies have proved to be useful in the treatment and management of diseases and are used extensively in ethnomedical and ethnoveterinary practice. The prohibitive cost of conventional medicines and their limited availability especially to rural communities in Africa and other developing regions have driven the continued dependence on traditional therapeutics. About 75-90\% of the world population still relies on plants and plant extracts as a source of primary health care (Benzie and Watchel-Galor, 2011). This widespread use of plant derived extracts in disease management has led to an interest in the identification and characterisation of the active compounds which give the extracts their therapeutic potential. The common wild fig, Ficus thonningii, is one of the many fruit-bearing trees that have traditionally been used for treating diseases in Africa and beyond. Despite its widespread use in ethnomedicinal systems, $F$. thonningii is a well known ornamental tree that is also used in improving agroforestic systems. Its leaves are used as fodder and its bark is used for making bark cloth. Like many woody trees, F. thonningii is commonly used in homesteads for fencing, firewood and construction (Orwa et al., 2009).

\section{Botany and taxonomy Botanical description}

F. thonningii is a multistemmed, evergreen or briefly deciduous tree with a dense, rounded to spreading crown. The tree is mainly distributed in the upland forests of tropical and subtropical Africa, at altitudes of between 1,000-2,500 m and grows best in light, deep and well drained soils (Hines and Eckman, 1993; Agroforestry tree Database, 2011). The leaves are alternate or whorled, mid-dark green and sub glossy above whilst paler below (Schmidt et al., 2002). They can be rounded or tapering, 4.5-12 cm long, hairless or finely hairy with a prominent midrib (Hyde and Wursten, 2011). The fruits which are borne singly or in pairs are round, $10-20 \mathrm{~mm}$ in diameter, usually hairy and turn yellowish and rarely pink when ripe (Schmidt et al., 2002). F. thonningii is a flowering tree that is pollinated by wasps which enjoy a symbiotic relationship and live in the syconium of its fruit and it can easily be propagated using seeds and cuttings (Agroforestry tree Database, 2011; Danthu et al., 2002).

\section{Taxonomy}

Although Ficus thonningii is clearly identified in West and Central Africa, there is much debate on its identification and taxonomy in Southern Africa where F. thonningii refers to a group of closely related species (Berg, 1990). Berg (1990) described the great variation under the $F$. thonningii complex and concluded that it is a complex of taxa that is difficult to separate satisfactorily on morphological criteria. As a result, Ficus rokko, Ficus rhodesiaca, Ficus burkei, Ficus petersii, 
Ficus persicifolia and a number of other Ficus species are all grouped under the Ficus thonningii complex (Burrows and Burrows, 2003; Schmidt et al., 2002).

Burrows and Burrows (2003), described a distinct variation between Ficus burkei (common wild fig) and Ficus petersii (Peter's fig), but they noted that even within F. burkei, there exists three distinct forms with just as much variation depending mainly on their geographical locations. In a bid to clarify the taxonomy and identification of $F$. thonningii in Southern Africa, Burrows and Burrows (2003) suggested that there is a possibility of interbreeding between species in overlapping geographical areas, resulting in hybrid intermediates.

It is important to note that although there are taxonomy issues surrounding the species, most of the trees grouped under the $F$. thonningii complex have the same name in the local African languages. For example the Shona name for $F$. rokko, F. natalensis, F. burkei and F. rhodesiaca) is 'Mutsamvi' (Hyde and Wursten, 2011; Burrows and Burrows, 2003). On the basis that the wild fig has the similar uses across the continent, this review focuses on the nutritional composition, ethnomedicinal uses, phytochemical composition, pharmacological properties and toxicology of the common wild fig.

\section{Nutritional benefits}

The leaves of $F$. thonningii are cooked as a vegetable by the Senegalese (Gueye and Diouf, 2007) and the Igede and Fulani people of Nigeria (Igoli et al., 2005; Lockett and Grivetti, 2000). The leaves are similarly used in Angola, Sudan, Kenya and Ethiopia. The leaves are a good source of protein ranging from 18.7-20.5 g/100 g dry matter (Tegbe et al., 2006) and therefore have potential to mitigate against protein deficiency diseases particularly in drought prone areas where food security is threatened. Ripe fruits of $F$. thonningii have been reportedly used for jam and alcoholic beverages (Orwa et al., 2009). However, we did not find any reports in refereed literature on the nutritional and/or phytochemical composition of the fruit.Generally, figs and fig leaves are known good sources of minerals (Lockett et al., 2000). F. thonningii leaves have a high ash content (upto17.34\% weight/weight) (Jokthan et al., 2003) containing high levels of calcium, 18.7-20.5 mg/100 g dry weight and remarkably high levels of potassium $(910-1250 \mathrm{mg} / 100 \mathrm{~g}$ dry weight) and magnesium $(260-357.2 \mathrm{mg} / 100 \mathrm{~g}$ dry weight) (Bamikole and Ikhatua, 2010; Tegegne, 2008). F. thonningii leaves contain high levels of crude fibre reaching up to $19.41 \% \mathrm{w} / \mathrm{w}$ (Tegbe et al., 2006). Owing to its good nutrient profile, $F$. thonningii is used as forage for ruminants (Bamikole and Ikhatua, 2010) and rabbits (Tegbe et al., 2006; Jokthan et al., 2003).

\section{Ethnomedicinal uses}

Leaves

Although all parts of the F. thonningii are medicinally useful, the latex-rich leaves are preferred because latex has been traditionally associated with potency (Ahur et al., 2010). Macerations of fresh $F$. thonningii leaves, taken orally, have been used by traditional healers for treating diarrhoea, gonorrhoea and diabetes mellitus (Njoronge and Kibunga, 2007). In Angola decoctions of $F$. thonningii leaves are used for treating wounds. The wounds are washed with the leaf extract whilst bleeding gums are rubbed with leaves in cases of gingivitis. Leaf extracts are also used for treating bronchitis and urinary tract infections (Cousins and Huffman, 2002). A decoction of the leaves is used in Mali for treating urinary schistosomiasis (Bah et al., 2006). In Nigeria, a maceration of the leaves is used for treating stomach pains, gastritis, gastric ulcers and other stomach conditions in animals (Nwude and Ibrahim, 1980). The leaves can also be used for treating liver disorders and disease conditions associated with jaundice (Ahur et al., 2010). Other medicinal uses of the leaves reported include treatment of bone movement disorders, ringworm, thrush, scabies and athlete's foot rot (Moshi et al., 2009; Alawa et al., 2002).

\section{Stem Bark}

Traditionally, the stem bark is pounded and the infusion used for treating influenza, sore throat, colds, arthritis, rheumatism and to relieve inflammation (Dalziel, 1937, Orwa et al., 2009). In Tanzania, it is also used to stimulate lactation (Minja, 1994) and in Mali and Senegal, to treat respiratory diseases such as emphysema (Prelude medicinal plants database, 2011). Further down, in Central Africa, Congo Brazaville, the bark is used for treating diarrhoea, cysts, skin diseases and ulcers (Teklehaymanot and Gidday, 2007). Other people use the bark decoction to enhance fertility and induce the menstrual cycle (Watt and Breyer-Brandwijk, 1962). In Southern Africa it is used as relief for constipation and bowel disorders (Gelfand et al., 1985)

\section{Roots}

The roots are used for the treatment of malaria, fever, hepatitis and dental pains (Prelude, 2011). In Zimbabwe roots have been reportedly used for preventing miscarriages and for stopping nose-bleeding (Gelfand et al., 1985). Additionally, the roots are also used for relieving stomach pains, diarrhoea, pneumonia and chest pains (Njoronge and Kibunga, 2007; Teklehaymanot and Gidday, 2007). An interesting use of the roots is in the treatment of diseases believed to be caused by evil spirits (Wondimu et al., 2007). The use of plants for treatment of "spiritual diseases" is an interesting dimension of ethnomedicine that however is very difficult to validate scientifically. 
F. thonningii exudes a white, sticky latex that turns pinkish with time (Arbonnier, 2004). The latex has been traditionally used for treating fever, tooth decay and ringworm (Arbonnier, 2004; Alawa et al., 2002), cataract in the eye (Alawa et al., 2002), as a vermifuge (Mali and Mehta, 2007), and as a galactagogue (Kilewe et al., 1988).

\section{Use of F. thonningii in combination with other plants}

In ethnomedicine, plants are often combined with other plants or herbs to enhance their curative effects due to synergism (Evans et al., 2002). F. thonningii is combined with soursop (Anona muricata), basil (Ocimum gratissium) and bamboo (Bambusa vulgaris) to prepare a remedy for treating respiratory diseases (Diafouka, 1997). In Mali, F. thonningii leaves are combined with the leaves and fruits of the African Palmyra palm (Borassus aethiopum) and the mixture is used for massaging, bathing and fumigating those suffering from paralysis and polio (Malgras, 1992).

\section{Phytochemical composition}

F. thonningii contains various biologically active compounds that exhibit physiological effects which could be responsible for its curative potential in a broad range of disease conditions. These non-nutritive chemicals, commonly known as phytochemicals, are naturally produced by the tree as protection against biotic and abiotic stresses. Most researchers used standard qualitative methods for screening for phytochemicals in F. thonningii. Qualitative methods can only confirm the presence or absence of a class of compounds without quantifying the specific bioactive compound. Little has been done to isolate and quantify specific compounds found in $F$. thonningii. The main groups of phytochemicals isolated from $F$. thonningii are: alkaloids, terpenoids, flavonoids, tannins and essential oils.

Flavonoids: Flavonoids have been found in various plant parts of F. thonningii (Ndukwe et al., 2007; Usman et al., 2010; Greenham et al., 2007). Greenham et al (2007) used flavonoids as a biomarker for determining variation in Ficus species. Flavone-C-glycosides have been shown to be present in F. thonningii leaves and these were further identified as orientin, vitexin and isovitexin. Amongst the Ficus species used in this phylogenetic assessment, F. thonningii was the only species that contained stilbenes which were identified as resveratrol, resveratrol glucosides and stilbene glucosides. Stilbenes are a special type of flavonoid produced by plants in response to pathogens and other abiotic stresses such as UV radiation (Chong et al., 2009). Resveratrol and its glycosylated derivatives are derived from the phenylpropanoid pathway and have numerous implications in plant disease resistance and human health as they elicit biological and pharmacological activity (Vitrac et al., 2004).

Tannins: Using the vanillin assay, tannin concentrations in F. thonningii leaves have been estimated to be about $90 \mathrm{mg} / 100$ g dry matter (Bamikole et al., 2004). The ferric chloride test and the tannic acid test have confirmed the presence of tannins in methanolic, n-butanolic and aqueous extracts of F. thonningii leaves (Ndukwe et al., 2007; Usman et al., 2009).

Alkaloids: Alkaloids are low molecular weight, nitrogen containing compounds that have remarkable physiological effects (Ramawat et al., 2009). This has led to their use as pharmaceuticals, stimulants and narcotics). F. thonningii contains alkaloids (Ndukwe et al., 2007, Ahur et al., 2010) but reports of specific alkaloids isolated from $F$. thonningii are scanty in literature.

Terpenoids: Triterpenoids are derived biosynthetically from squalene (Harbone, 2008) and produce several pharmacologically active groups such as steroids, saponins and cardiac glycosides (Ramawat et al., 2009). Triterpenes isolated in F. thonningii stem bark extracts include saponins and anthraquinone glycosides (Ndukwe et al., 2007; Usman et al., 2009). Saponin concentrations in F. thonningii leaves were shown to be as high as $300 \mathrm{mg} / 100 \mathrm{~g}$ dry matter (Bamikole et al., 2004).

The Moraceae family is a rich plant source of cardiac glycosides which are ubiquitous in the Ficus genus e.g. in F. racemosa, F. religiosa (Joseph and Raj, 2011); Poongothai et al, 201. Cardiac glycosides are inhibitors of $\mathrm{Na}^{+} / \mathrm{K}^{+}$-ATPase and have been used in the treatment of heart failure and atrial arrhythmias (Prassas and Diamandis, 2008).

Essential oils: F. thonningii leaves contain essential oils composed mainly of 6, 10, 14 trimethyl-2-pentadecanone (18.8\%), phytol (14.7\%), acorenone (7.6\%) and $\beta$-gurjunene (6.3\%) (Ogunwande et al., 2008).

Other phytochemicals: Other phytochemicals with antinutritional properties present in $F$. thonningii include phytate (130 $\mathrm{mg} / 100 \mathrm{~g} \mathrm{DM})$ and oxalate $(230 \mathrm{mg} / 100 \mathrm{~g} \mathrm{DM})$ (Bamikole et al., 2004). Despite the presence of these antinutritional factors, the leaves of $F$. thonningii still possess high feed value evidenced by their high palability and digestibility when used as fodder. F. thonningii leaves were shown to contain other secondary metabolites such as lignins, lignans, active carbohydrates and proteins which might also add to its remarkable pharmacological and biological activity (Ahur et al., 2010).

\section{Pharmacological activity Antimicrobial effects}

Antibiotics have proven very effective in the fight against infectious diseases. However, inappropriate use and abuse of antibiotics has led to the development of antibiotic-resistant, pathogenic microbial strains. As a result, there is a great interest in the search for alternative, plant-based medicines with antimicrobial activity. The antimicrobial activity of the Ficus genus is well documented (Kuete et al., 2009; Kuete et al., 2008; Mandal et al., 2000). 
The antimicrobial activity of plant medicines seems to depend on the efficacy of the extraction and the solvent used plays an important role (Cowan, 1999). In traditional medicine, palm wine is sometimes used in place of water in the preparation of remedies (Aibinu et al., 2007). Most of the antimicrobial bioactive compounds are aromatic or saturated organic compounds and hence can easily be extracted using ethanol or methanol. However, some compounds partition exclusively in particular solvents e.g. xanthoxylines, totarol, quassinoids, lactones and phenones will partition in methanol only, while polyacetylenes, sterols and propolis will partition in ethanol (Cowan, 1999). From their results on the antimicrobial properties of $F$. thonningii, Usman and colleagues (2009) reported that n-butanol and residual aqueous extracts had better antimicrobial activity than crude methanolic extracts.

Table 1 summarises the specific antibacterial effects of $F$. thonningii extracts. F. thonningii contains other phytochemicals that exhibit antibacterial activity. Flavonoids are known to complex with extracellular and soluble proteins as well as with bacterial cell walls (Cowan, 1999). Tannins have an ability to inactivate microbial adhesions, enzymes and cell envelope proteins and may complex with polysaccharides (Ya et al., 1988, Cowan, 1999). Aromatic alkaloids have also been reported to intercalate with DNA and thus are potential antimicrobial agents (Raaman, 2006). Terpenoids are known to disrupt microbial cell membranes and hence give plants bactericidal effects (Cowan, 1999). Phytol, a diterpene found in $F$. thonningii has been shown to possess antibacterial effects. The mean inhibitory concentration of phytol (2 mg/ml) against Mycobacterium tuberculosis was comparable to that of ethambutol (0.95-3.8 mg/ml) (Rajab et al., 1998).

\section{Antiprotozoal_properties}

Traditional healers report the use of $F$. thonningii in the treatment for malaria (Chinsembu and Hedimbi 2010; Titanji, 2008). A study carried out to evaluate the antiplasmodial activity of $F$. thonningii against Plasmodium falciparum the protozoan parasite that causes malaria reported no significant antiplasmodial activity (Jansen et al., 2010). F. thonningii possibly just possesses good insect repellent properties and hence reduces the contact of the vector with humans, minimising incidence of malaria transmission (Jansen et al., 2010; Innocent, 2008). Amongst the compounds isolated in F. thonningii essential oils is the C-15 compound; 6, 10, 14 trimethyl-2-pentadecanone an aliphatic methyl ketone which has been reported to possess insect repellent properties. The repellent properties of 6,10,14 trimethyl-2-pentadecanone at a concentration of 10 $\%(\mathrm{w} / \mathrm{v})$, were comparable to those of the commercial repellent, N, N diethyl-m-toluamide (DEET) (Innocent, 2008).

Using mice inoculated with Trypanosoma brucei gambiense, Youan et al, (1997) reported that F. thonningii possessed neither trypanocidal nor trypanostatic activities against the parasite. They reported a survival rate of $0 \%$ in mice after three days of inoculation as compared to that of $100 \%$ for the controls melarsoprol and pentamidine both of which are commercial drugs used in the treatment of human African trypanosomiasis. However, $F$. thonningii was shown to exhibit high amoebicidal activity against Entamoeba hystolytica at a concentration of $100 \mu \mathrm{g} / \mathrm{ml}$ as compared to the control metronidazole, a commercial drug (Moundipa et al., 2005).

\section{Antifungal activity}

The traditional use of $F$. thonningii in the treatment of athelete's foot rot suggests that the presence of antifungal compounds. Oyelana et al., (2011) showed that leaf extracts of $F$. thonningii $(25$ and $50 \mathrm{mg} / \mathrm{ml}$ ) had antifungal activity against Aspergilus niger, Aspergilus flavus, Botryodiploidia theobromae, Fusarium oxysporum, Fusarium solani, Penicillium chrysogenum, Penicillium oxalicum and Rhizopus stolonifer. The extracts were also reported to show a significant arrest of mycelia growth. Another study carried out on Ficus microcarpa (synonym for F. thonningii, in South Asia), reported the presence of two antifungal chitinases from the latex of its aerial roots (Taira et al., 2005). These proteins, GLx Chi-C and Chi-B, exhibit strong antifungal activity by binding to fungal cell walls and hydrolysing the fungal cell wall component, chitin (Taira et al., 2005; Hou et al., 1998).

\section{Anthelmintic properties}

The proteolytic compound ficin in Ficus thonningii latex justifies its use as an anthelmintic agent. Ficin is a cysteine endopeptidase that is found in the latex of many Ficus spp and is known to digest living intestinal parasites (Etkin and Ross, 1982; Krief et al., 2005). This is in harmony with the reports that the tree is used as a vermifuge (Mali and Mehta, 2007)

\section{Antioxidant}

Flavonoids are good antioxidants which scavenge and reduce free radical formation (Grassi et al., 2010). The Cglucosylflavonoids (orientin, vitexin and isovitexin) isolated from $F$. thonningii possess antioxidant properties and have been identified in many medicinal plants such as the pigeon pea (Trollius ledebouri Reichb), linseed oil (Linum usitatissimum) and in rooibos tea (Aspalathus linearis) (Joubert and Ferreira, 1996; Von Gadow et al., 1997). Orientin possesses free radical scavenging activity based on its ene-diol functionality i.e. its dihydroxy substituents in the B ring and the double bond characteristic of the C-ring (Joubert and Ferreira, 1996). Vitexin and isovitexin have also been reported to possess antioxidant activities though to a lesser extent than orientin due to a missing $\mathrm{OH}$ on the $\mathrm{C}$ ring. In addition to flavonoid antioxidant activity, the stilbenes present in F. thonningii also exhibit antioxidant activity. Resveratrol and its methylated derivative, 


\section{http://dx.doi.org/10.4314/ajtcam.v10i2.4}

Table 1: Antibacterial activity of Ficus thonningii extracts and common diseases associated with the specific bacteria.

\begin{tabular}{l|ll|ll} 
Plant part & $\begin{array}{l}\text { Susceptible } \\
\text { microorganism }\end{array}$ & MIC & Reference & Common diseases associated with microorganism
\end{tabular}

Ethanolic leaf Streptococcus pyrogenes

extracts

(Group A)

Beta- haemolytic

$23 \mu \mathrm{g} / \mathrm{ml} \quad$ Kone et al., $2004 \quad$ Tonsilitis, septicaemia, rheumatic fever

$47 \mu \mathrm{g} / \mathrm{ml} \quad$ Kone et al., 2004

Enterococcus faecalis $\quad 94 \mu \mathrm{g} / \mathrm{ml} \quad$ Kone et al., $2004 \quad$ Urinary tract infections

(aminoside resistant)

Kone et al., $2004 \quad$ Urinary tract infections

n-butanolic Escherichia coli $\quad 1.25 \mathrm{mg} / \mathrm{ml} \quad$ Usman et al., $2009 \quad$ Urinary tract infections, neonatal meningitis

stem -bark

extracts

Aqueous stem- Staphylococcus aureus $\quad 1.25 \mathrm{mg} / \mathrm{ml} \quad$ Usman et al., 2009

bark extracts

$1.25 \mathrm{mg} / \mathrm{ml} \quad$ Usman et al., 2009

Urinary tract infections, pneumonia and wound infections

Klebsiella spp

(

Psedomonas aeruginosa $\quad 2.5 \mathrm{mg} / \mathrm{ml} \quad$ Usman et al.,2009

Pulmonary infections, urinary tract infections, gastroenteritis

Methanolic Bacillus subtilis $\quad 12.5 \mathrm{mg} / \mathrm{ml} \quad$ Ndukwe et al., 2007 Generally non-pathogenic

stem-bark

extracts

Salmonella typhi $\quad 1.25 \mathrm{mg} / \mathrm{ml} \quad$ Ndukwe et al., $2007 \quad$ Enteric fever, gastroenteritis

$\begin{array}{lll}\text { Providencia stauti } \quad 6 \mathrm{mg} / \mathrm{ml} \quad \text { Ndukwe et al., } 2007 & \begin{array}{l}\text { Nosocomial infections, urinary tract infections, } \\ \text { respiratory tract infections and wounds }\end{array}\end{array}$


trans-3.3', 5.5- tetrahydroxy-4-methoxystilbene, possess antioxidative effects against oxidative stress induced by reactive nitrogen species and reactive oxygen species (Olas et al., 2008; Olas et al., 2003). Resveratrol and its derivatives have also been shown to reduce peroxynitrite which is one of the most potent reactive nitrogen species (Olas et al., 2008). High levels of peroxynitrite are generated in inflammation based disease conditions (Ischropoulos and Al Mehdi, 1995). The antiinflammatory properties of $F$. thonningii are probably a result of the action of these stilbenes and flavonoids. There is also a likelihood of synergistic interactions between the flavonoids and stilbenes that are present in F. thonningii (Wu et al., 2009). Owing to its antioxidant activities, $F$. thonningii has been shown to possess protective effects on the erythrocyte membrane from acetaminophen induced membrane peroxidation (Ahur et al., 2010). The antihaemolytic and haematinic potential is possibly due to its antagonistic activity against the depletion of glutathione and hence prevention of the generation of free radicals which result in oxidative stress (Ahur et al., 2010)

\section{Analgesic effects}

F. thonningii has been reported to possess analgesic properties that are comparable to aspirin in both peripheral and central induced pain. Using the acetic acid induced writhing reflex model in mice, Otimenyin (2004) demonstrated that methanolic extracts of $F$. thonningii $(500 \mathrm{mg} / \mathrm{kg})$ administered intraperitoneally had a percentage inhibition $(79.7 \%)$ comparable to aspirin $(80 \%)$ showing that $F$. thonningii has analgesic effects that can be useful in the management of peripherally induced pain. Otimenyin (2004) also reported the analgesic effects of the plant in central pain using the hot plate test method in mice.

\section{Anti-inflammatory effects}

The anti-inflammatory properties of $F$. thonningii have been validated using egg albumin and carageenan induced oedema in rats (Otimenyin, 2004; Coker et al., 2009). Phytol, the aliphatic diterpene found in F. thonningii has antiinflammatory effects and has been reported as a potential therapeutic agent for the treatment of rheumatoid arthritis and possibly other chronic inflammatory diseases such as asthma (Ogunlesi et al., 2009). Unsaturated phytol exhibits antioxidant activity and is believed to be the side group that gives tocotrienols their higher antioxidative effects as compared to tocopherols (Yu et al., 2005).

\section{Cardioprotective effects}

Ficus thonningii possesses cardio-suppressant and hypotensive properties. Ethanolic stem bark extracts of $F$ thonningii were shown to exhibit positive chronotropic and inotropic effects on both electronically driven and spontaneously beating atrial muscle strips (Musabayane et al., 2007). This study also reported an attenuating effect of $F$. thonningii extracts $(120 \mathrm{mg} / \mathrm{kg}$ b.w given for 5 weeks) on mean arterial pressures. The cardioprotective effects of $F$. thonningii could be credited to the presence of resveratrol. Resveratrol has been reported to prevent and slow the progression of various diseases which include cancer and cardiovascular diseases (Baur and Sinclair, 2006). It has also been shown to possess vasoprotective and reno-protective effects (Ramawat et al., 2009).

\section{Hypoglycemic effects}

Ethanolic extracts of $F$. thonningii have been shown to exhibit hypoglycaemic effects in rats (Bwititi and Musabayane, 1997). Oral glucose tolerance tests performed on diabetic and non diabetic rats treated with stem bark ethanolic extracts of F. thonningii showed a dose dependant hypoglycaemic effect comparable to that of metformin which was used as a positive control (Musabayane et al., 2007). These hypoglycemic effects validate the ethnomedicinal use of the plant extracts in the treatment of diabetes mellitus. The presence of phytol in $F$. thonningii could contribute to its hypoglycaemic effect. Phytanic acid, a compound produced from the metabolism of phytol is also reported to possess hypoglycaemic and hypolipidaemic effects as shown by Heim et al. (2002). In rats, phytanic acid increases the expression of glucose transporters and glucokinase and hence increases glucose uptake in the hepatocytes (Heim et al., 2002). F. thonningii extracts also contain the stilbene resveratrol which has been reported to exhibit hypoglyglemic effects by enhancing glucose uptake by muscle cells and by activating hepatic AMPK (Minikawa et al., 2011)

\section{Antineoplastic effects}

We were not able to find any published report on the tumoricidal and antimutagenic properties of $F$. thonningii. However, other related species such as Ficus hispida (Linn) have been shown to exhibit antineoplastic activity against human breast cancer cell lines (Pratumvinit et al., 2009). Aqueous extracts of Ficus carica were shown to inhibit Ehrlich's ascite carcinoma, $\mathrm{S}_{180}$ sarcoma, Hep A hepatocarcinoma and Lewis lung carcinoma (Ma et al., 2002). There is thus need to investigate the potential antineoplastic effects of $F$. thonningii extracts.

\section{Antidiarrheal effects}

F. thonningii is extensively used for treating diarrhoea in both livestock and humans (Njoronge and Kubunga, 2009). The antimicrobial properties are usually the result of the anti-secretory, anti-inflammatory and antibacterial effects of tannins and astringent phenolics such as triterpenoids and saponins. Tannins and tannic acid reduce secretion by denaturing proteins of the intestinal mucosa forming protein tannates which make the mucosa more resistant to chemical alteration 
(Tripathi, 1994). Plants with anti-diarrhoeal properties also act by decreasing intestinal motility, stimulating water absorption and reducing electrolyte secretion (Njoronge and Bussman, 2006).

\section{Toxicology}

The scientific validation of potential acute and chronic toxic effects of plant medicines is crucial in light of their widespread use and the common misconception that green medicine is always safe.

\section{Acute toxicity}

An acute toxicity study was carried out by Aniagu et al. (2008) to investigate the short term toxic effects of aqueous $F$. thonningii leaf extracts in adult Wistar rats. The $\mathrm{LD}_{50}$ of extracts administered orally was shown to be above 3000 $\mathrm{mg} / \mathrm{kg}$ body weight. Animals showed $100 \%$ mortality after intraperitoneal administration of $600 \mathrm{mg} / \mathrm{kg}$ body weight of the same extracts and the $\mathrm{LD}_{50}$ intraperitoneally was reported to be $584 \mathrm{mg} / \mathrm{kg}$. In another acute toxicity test, the median lethal dose of ethyl acetate leaf extracts of Ficus thonningii administered orally was shown to be above $5000 \mathrm{mg} / \mathrm{kg}$ body weight in adult Wistar rats (Ahur et al., 2010).

\section{Sub-chronic / Chronic toxicity}

Studies carried out to evaluate the sub-chronic and chronic effects demonstrate that $F$. thonningii is safe if used in low doses. Coker et al. (2009) reported no histopathological changes in the liver, kidney, spleen, ovary, uteri and lungs of adult female Wistar rats treated with methanolic extracts $(200,400$ and $1000 \mathrm{mg} / \mathrm{kg}$ body weight $)$ of $F$. thonningii leaves for 21 days. Oral administration of aqueous extracts $(250$ and $500 \mathrm{mg} / \mathrm{kg}$ body weight) for 15 days in adult Wistar rats resulted in no mortality, no haematological derangements and no clinical signs of toxicity observed within 72 hours after administration (Aniagu et al., 2008). Their histopathological findings however suggested possible testicular, hepatic and lung toxicities (Aniagu et al., 2008).

\section{Cytotocixity}

The cytotoxicity of stem-bark ethanolic extract of Ficus thonningii on kidney cell lines was investigated by Musabayane et al. (2007). No toxicity was observed in both distal and proximal tubule cell lines after treatment with plant extracts $(600-100 \mu \mathrm{g} / \mathrm{ml})$. Distal tubule cells lines showed a dose dependent increase in metabolism and viability.

\section{Conclusions and Perspectives}

Ficus thonningii is extensively used by ethnomedical practitioners for treating various ailments. The pharmacodynamic basis supporting the use of $F$. thonningii extracts in ethnomedicinal systems has been established and pharmacological studies have demonstrated the anti-inflammatory, analgesic, antimicrobial, anthelmintic, antioxidant, cardioprotective, hypotensive and hypoglycaemic effects of the plant extracts. The remarkable therapeutic effects exhibited by $F$. thonningii are a result of the presence of an array of phytochemicals which include flavonoids, alkaloids, tannins, stilbenes, terpenoids and other active proteins. However, instead of merely screening for the presence or absence of broad phytochemical classes, researchers should seek to identify and quantify the specific compounds that are responsible for the physiological effects that $F$. thonningii exhibits. Further elucidation of the molecular mechanisms underlying the activity of these chemicals is also critical to evaluate the possibility of using the plant extracts for future drug development. Research could also shed light on the effect of $F$. thonningii on the nervous system, the endocrine system as well as its interaction with the immune system in fighting disease. More work can be done to characterise the nutritional and phytochemical composition of $F$. thonningii fruits and to evaluate their use as both a dietary and medicinal supplement.

\section{References}

1. Agroforestry Tree Database. 2011. (http://www.worldagroforestrycentre.org/sea/Products/AFDbases/AF/ asp/speciesInfo.asp?SpID=866 ) accessed 03/07/11.

2. Ahur, V.M., Madubunyi, I., Adenkola, A.Y. and Udem, S.C. (2010). The effect of acetyl acetate extract of Ficus thonningii (Blume) leaves on erythrocyte osmotic fragility and haematological parameters in acetaminophentreated rats. Com. Clin. Pathol., 10: 1107-1111.

3. Aibinu, I.E., Akinsule, O.R., Adenipekun, T., Adelowotan, T. and Odugbemi, T. (2007). In vitro antimicrobial activity of crude extracts from plants Bryophyllum pinnatum and Kalanchoe crenata. AJTCAM, 4: 338-344.

4. Alawa, J. P., Jokthan, G.E. and Akut, K. (2002). Ethnoveterinary medical practice for ruminants in the sub-humid zone of the northern Nigeria. Prev. Vet. Med., 54: 79-90.

5. Aniagu, S.O., Nwinyi, F.C., Akumka, D.D., Agbain, E.O., Dzarma, S., Ajoku, P., Adelusola, K.A., Ibe, J., Inyang, U.S. and Gamaniel, K.S. (2008). Short term toxicity studies of Ficus thonningii Blume Moraceae leaf extracts in rats. Int. J. Food Sci Tech 43: 456-464. 
6. Arbonier, M.A. (2004). Trees, Shrubs and Lianas of West African Dry Zones. $2^{\text {nd }}$ edition, Margraf publishers, Netherlands, pp. 412.

7. Bah, S., Diallo, D., Dembele, B. and Paulsen, S. (2006). Ethnopharmacological survey of plants used for the treatment of schistosomiasis in Niono district, Mali. J. Ethnopharmacol., 105: 387-399.

8. Bamikole, M.A., Ikhatua, U.J., Arigbede, M.O., Babayemi, O.J., Etela, I. (2004). An evaluation of the acceptability as forage, of some nutritive nad antinutritive components of the dry matter degradation profiles of five species of Ficus. Trop. Anim. Health Prod., 36: 157-167.

9. Bamikole, M.A. and Ikhatua, U.J. (2010). Nutritional evaluation of Ficus thonningii-Panicum maximum mixtures in West African dwarf goats. Nutrition and Food Science, 40: 280-288.

10. Baur, J.A. and Sinclair, D.A. (2006). Therapeutic potential of resveratrol: The in vivo evidence. Nat. Rev. Drug Discov., 5: 493-506.

11. Benzie, I.F.F. and Watchtel-Galor, S. 2011. Herbal Medicine: Biomolecular and Clinical Aspects. $2^{\text {nd }}$ edition. CRC Press, pp. 2.

12. Berg, C.C. (1990). Annotated checklist of the Ficus species of the African floristic region with special reference and a key taxa of southern Africa. Kirkia, 13: 268-269.

13. Burrows, J. and Burrows, S. (2003). Figs of southern and south-central Africa, Umdaus Press. Hatfield, South Africa.

14. Bwititi, P. and Musabayane, C.T. (1997). The effect of plant extracts on plasma glucose in rats. Acta Med Biol., 45: $167-169$.

15. Chinsembu, K.C. and Hedimbi, M. (2010). An ethnobotanical survey of plants used to manage HIV/AIDS opportunistic infections in Katima, Caprivi region, Namibia. J. Ethnobiol. Ethnomed., 6: 25.

16. Coker, M.E., Emikpe, B.O., Adeniyi, B.A. and Budale, B.A. (2009). The inflammatory potential, haematological and histological changes induced in rats due to the administration of methanolic extracts of Ficus thonningii leaves. Afr. J. Pharm., 3: 273-276.

17. Cowan, M.M. (1999). Plant products as antimicrobial agents. Clin. Microbiol Rev., 12: 564-582.

18. Cousins, D. and Huffman, M.A. (2002). Medicinal properties in the diets of gorillas: an ethno-pharmacological evaluation. Afr. Study Monogr 23: 65-89.

19. Dalziel, J.M. (1937). The useful plants of west tropical Africa. The Crown Agents for the colonies, Westminister, London, pg 612.

20. Danthu, P., Solovier, P., Gaye, A., Sarr, A., Seck, M. and Thomas, I. (2002). Vegetative propagation of some West African species by cuttings. Agrofor. Sys., 55: 57-63.

21. Diafouka, A.J.P. (1997). Analyse des usages des plantes medicinales dans 4 regions de Congo Brazzaville. These de doctorat, Universite libre de Bruxelles, Faculte des Sciences, Laboratoire de Botanique Systematique et de Phytosociologie pg 431. In: Prelude medicinal plant database.

22. Etkin, N.L. and Ross, P.J., (1982). Food as medicine and medicine as food. An adoptive framework for the utilization among the Hausa of Nothern Nigeria. Soc Sci Med., 16: 1559-1573.

23. Evans, W.C., Trease, G.E. and Evans, D. (2002). Trease and Evans Pharmacognosy. $15^{\text {th }}$ edtion, Edinburgh, Saunders pp 249, 454.

24. Gelfand, M., Mavi, S., Drummond, R.B. and Ndemera, B. (1985). The Traditional Medicinal Practitioner. His principles of practice and pharmacopoeia. Mambo Press, Gweru, Zimbabwe, pp. 411.

25. Grassi, D., Desideri, D. and Ferri, C. (2010). Flavonoids antioxidants against atherosclerosis. Nutrients 2: 889-902.

26. Greenham, J.R., Grayer, R.J, Harbone, J.B. and Reynolds, V. (2007). Intra- and Interspeficic variations in vacuolar flavonoids among Ficus species from the Budongo forest, Uganda. Biochem. System Ecol., 35: 81-90.

27. Gueye, M. and Diouf, M. (2007). Traditional leafy vegetables in Senegal. Diversity and medicinal uses. AJTCAM., 4: $469-475$.

28. Harbone, J.B. (2008). Phytochemical methods: a guide to modern techniques of plant analysis. $3^{\text {rd }}$ edition, Chapman and Hall. (http://book.google.co.za/books?id=2yvqeRtE8CwC\&lpg=P) accessed 03/07/11.

29. Heim, M., Johnson, J., Boess, F., Bendik, I., Weber, P., Hunziker, W. and Fluhmann, B. (2002). Phytanic acid, a natural peroxisome proliferator activated receptor (PPAR) agonist, regulates glucose metabolism in rat primary hepatocytes. FASEB. J., 17: 718-720.

30. Hines, D.A. and Eckman, K. (1993). Indigenous multipurpose trees of Tanzania, Uses and economic benefits for people. FAO Corporate document repository. (http://www.fao.org/docrep/x5327e/x27e00.htm)

31. Hou, W.C., Chen, Y.C. and Lin, Y.H. (1998). Chitinase activity of sweet potato (Ipomoea batatas [L]. Lam var. Tainong 57). Bot. Bull. Acad. Sinica, 39: 93-97.

32. Hyde, M.A. and Wursten, B. (2011). Flora of Zimbabwe.(http://www.zimbabweflora.co.zw/speciesdata/utilities/utility/species-search-binomial, php) accessed $24 / 08 / 2011$

33. Igoli, J.O., Tor-Anyin, T.A., Usman, S.S., Oluma, H.O.A. and Igoli N.P. (2002). Folk medicines of the Beneu valley of Nigeria. In: Recent progress in Medicinal plants, Vol 7, Ethnomedicine and Pharmacognosy (Singh, V.K, Govil, J.N., Hashim, S. Sing G. ed.) Raleigh, NC, Science Technology Publishers, pp 327-338.

34. Innocent, E., Gikonyo, N.K. and Nkunya, M.H.H. (2008). Repellence property of long chain aliphatic methyl ketones against Anopheles gambiae s.s. Tanz J. Health Res., 10: 50-54.

35. Ischiropoulos, H. and Almehdi, A.B. (1995). Peroxynitrite mediated oxidative protein modifications. FEBS Lett, 364: $279-282$.

36. Jansen, O., Angenot, L., Tits, M., Nicolas, J.P., De Mol, P., Nikiema, J-B. and Frederich, M. (2010). Evaluation of 13 selected medicinal plants from Burkina Faso for their antiplasmodial properties. J. Ethnophamacol., 13: 143150 . 
37. Jokthan, G.E., Afikwu, E.V. and Olugbemi. (2003). The utilization of fig (Ficus thonningii) and mango (Mangifera indica) leaves by rabbits. Pakistan J. Nutr., 2: 264-266.

38. Joseph, B. and Raj, J.S. (2011). A comparative study on various properties of five medicinally important plants. Int J. Pharm. DOI: 10.3923/ijp.2011.

39. Joubert, E. and Ferreira, D. (1996). Antioxidants of rooibos tea a possible exploration for its health promoting properties?. The South African Journal of Food Science and Nutrition, 8: 79-83.

40. Kilewe, A.M., Kealay, K.M. and Keboara, K.K. (1988). Agroforestry Development in Kenya: Proceedings of the Second Kenya National Seminar on Agroforestry, held in Nairobi, Kenya.

41. Krief, S., Hladik, C.M. and Haxaire, C. (2005). Ethnomedicinal and bioactive properties of plants ingested by wild chimpanzees in Uganda. J. Ethnopharmacol., 101: 1-15.

42. Kuete, V., Ngameni, B., Fotso, S.C.C, Kengap, T.R, Ngadjui, B.T., Meyer, J.J.M., Lall, N. and Kuiate, J.R. (2008). Antimicrobial activity of the crude extracts of and compounds from Ficus chlamydocarpa and Ficus cordata (Moraceae). J. Ethnopharmacol., 120: 17-24.

43. Kuete, V., Nana, F., Ngameni, B., Mabveng, T.A., Keumedjio, F. and Ngadjui, B.T. (2009). Antimicrobial activity of the crude extract, fractions and compounds from stem bark of Ficus ovata (Moraceae). J. Ethnopharmacol., 124: 556-561.

44. Locket, C.T., Carlvett, C.C. and Grivetti, L.E. (2000). Food-related behaviours during drought: A Study of rural Fulani, North Eastern Nigeria. Int. J. Food Sci. Nutr., 51: 91-107.

45. Ma, G.J., Meng, Z.M, Wang, Y.X, Zhang, Q.F. and Xue, K.X. (2002). Study on the mutagenic and antimutagenic effects of the fig extract. Teratogen. Carcin. Mut, 14: 177-180.

46. Malgras, D. (1992). Arbes et arbustes guerissuers des savanes maliennes. Editions Karthala, 22-24, Boulevard Arago, 75013, Paris, pg 480, In: Prelude medicinal plants database, 2011.

47. Mali, R.G. and Mehta, A.A. (2007). A review on anthemintic plants. Nat. Prod. Rad., 7: 466-475.

48. Mandal, S.C., Saha, B.P. and Pal, M. (2000). Study on antimicrobial activity of Ficus racemosa Linn leaf extract. Phytother. Res., 14: 278-280.

49. Minikawa, M., Kawawo, A., Miura, Y. and Yagasaki, K. (2011). Hypoglycemic effect of resveratrol in type 2 diabetes model $\mathrm{db} / \mathrm{db}$ mice and its actions in cultured L6 myotubes and RIN-5F pancreatic $\beta$-cells. J. Clin Biochem. Nutr, 48: 237-244.

50. Minja, M.M.J. (1994). Medicinal plants used in promotion of animal health in Tanzania. Animal Diseases Research Insit. Presses Universitaires de Namur, Dar Es Salaam, pp. 335-364.

51. Moshi, M.J., Otieno, D.F., Mbabazi P.K. and Weisheit. A. (2009). The ethnomedicine of the Haya people of Bugabo ward, Kagera Region, North-western Tanzania. J. Ethnobiol Ethnomed., 5: 24.

52. Moundipa, P.F., Flore, K.G.M., Bilong, C.F.B. and Bruchhaus, I. (2005). In vitro amoebacidal activity of some medicinal plants of the Bamun region (Cameroon). AJTCAM., 2: 113-121.

53. Musabayane, C.T., Gondwe, M., Kadyamaapa, D.R., Chuturgoon, A.A. and Ojewole, J.A.O. (2007). Effects of $F$. thonningii (Blume) Moraceae stem bark ethanolic extract on blood glucose, cardiovascular and kidney cell lines of the proximal (LLC-PK1) and distal tubules (MDBK). Ren Fail., 29: 389-397.

54. Ndukwe, I.G., Bello, A.I., Habila, J.D. and John, C. (2007). Phytochemical and antimicrobial screening of the crude petroleum spirit and methanol extracts of the stem bark, leaves and roots of Ficus thonningii (Blume). Afr. J. Biotechnol., 16: 2645-2649.

55. Njoronge, G.N. and Bussmann, R.W. (2006). Herbal usage and informant concensus in ethnoveterinary management of cattle diseases among Kikuyus (Central Kenya). J. Ethnopharmacol., 108: 332-339.

56. Njoronge, G.N. and Kibunga J.W. (2007). Herbal medicine acceptance, sources and utilisation for diarrhoea management in a cosmopolitan urban area (Thika, Kenya). Afr. J. Ecol., 45: 65-70.

57. Nwude, N. and Ibrahim, M.A. (1980). Plants used in traditional veterinary medical practice in Nigeria. J. Vet. Pharmacol.Ther., 3: 271-273.

58. Ogunlesi, M., Okiei, W., Ofor, E. and Osibote, E.A. (2009). Analysis of the essential oils from the dried leaves of Euphorbia hirta Linn (Euphorbiaceae), a potential medication for asthma. Afr. J. Biotechnol, 8: 7042-7050.

59. Ogunwade, I.A., Sonibare, M.A., Thangi, T.D., Dung, N.X., Soladaye, M. O. and Monohunfolu, O.O. (2008). Comparative analysis of the oils of three Ficus species from Nigeria. J. Essent Oil Res., 20

60. Olas, B., Wachowiz, B., Stochmal, A. and Oleszek, W. (2003). Inhibition of oxidative stress in blood platelets by different phenolics from Yucca schidigera Roezl. Bark Nutrition, 19: 633-40.

61. Olas, B., Wachowicz, B., Nowak, P., Stochmal, A., Oleszek, W., Glowacki. and Bald, E. (2008). Comparative studies of the antioxidant effects of a naturally occurring resveratrol analogue trans 3, 3, 5, 5-tetrahydroxy-4methoxystilbene and resveratrol- against oxidation and nitration of biomolecules in blood platelets. Cell Biol Toxicol, 24: 331-340.

62. Orwa, C., Mutua, A., Kindt, R., Jamnadass, R. and Anthony, S. (2009). Agroforestry Tree Database: A tree reference and selection guide version 4.0. (http://www.worldagroforestry.org/sites/treedbs/treedatabases.asp accessed on12/6/11)

63. Otimenyin, S.O., Uguru, M.O. and Atang, B.L. (2004). Anti-inflammatory and analgesic activities of Ficus thonningii and Pseudocedrela kotschyi extracts. Nig. J. Pharm. Res, 3: 82-85.

64. Oyelana, O.A., Durugbo, E.U., Olukanni, O.D., Ayodele, E.A., Aikulola, Z.O. and Adewole, A.I. (2011). Antimicrobial activity of Ficus leaf Extracts on some fungal and bacterial pathogens of Dioscorea rotundata from Southwest Nigeria. J. Bio. Sci, 11: 359-366.

65. Poongothai, A., Sreena, K.P., Sreejith, K., Uthiralingam, M. and Annapoorani, S. (2011). Preliminary phytochemical screening of Ficus racemosa Linn bark. International Journal of Pharma and Bio-sciences, 2: 431434. 
66. Prassas, I. and Diamandis, E.P. (2008). Novel therapeutic applications of cardiac glycosides. Nat. Rev. Drug Discov., 7: 926-935.

67. Pratumvinit, B., Srisapoomi, T., Worawattananon, P., Opartkiattikul, N, Jiratchariyakul, W. and Kummalue, T. (2009). In vitro antineoplastic effect of Ficus hispida L. plant against breast cancer cell lines. J. Med. Plants Res., 3: $255-261$.

68. Prelude medicinal plants database. (2011). (http://www.metafro.be/prelude/view_plant?pi=06040 accessed 27/04/11.)

69. Raaman, N. (2006). Phytochemical Techniques. New India Publishing, India, pp. 228.

70. Rajab, M.S., Cantrell, C.L., Franzblau, S.G. and Fischer, N.H. (1998). Antimycobacterial activity of (E)-phytol and derivatives: a preliminary structure activity study. Planta Med., 64: 2-4.

71. Ramawat, K.G., Doss, S. and Mathura, M. (2009). The chemical diversity of bioactive molecules and Therapeutic potential of medicinal plants. In: Ramawat, K.G., (eds.), Herbal Drugs Ethnomedicine to Modern Medicine, Springer-Verlag Berlin Heidelberg, pp. 7-31.

72. Schmidt, E., Lutter, M. and McCleland, W. (2002). Trees and shrubs of Mpumalanga and Kruger National Park, Jacana, South Africa, pp. 80.

73. Taira, T., Ohdomari, A., Nakama, N., Shinioj, M. and Ishihara, M. (2005). Characterization of antifungal activity in gazyumaru (Ficus microcarpa) latex chitinases: both the chitin binding and the antifungal activities of class 1 chitinase are reinforced with increasing ionic strength. Biosci. Biotech. Biochem, 69, 811-818.

74. Tegbe, T.S.B., Adeyinka, I.A., Baye, K.D. and Alawa, J.P. (2006). Evaluation of feeding graded levels of dried and milled Ficus thonningii leaves on growth performance, carcass characteristics and organ of weaner rabbits. Pakistan J. Nutr., 5: 548-550.

75. Tegegne, E.D., (2008). Importance of Ficus thonningii Blume in Soil Fertility Improvement and Animal Nutrition in Gondar Zuria, Ethiopia. Masters thesis, University of Natural Resources and Applied Life Science, Vienna.

76. Teklehaymanot, T. and Gidday, M. (2007). Ethnobotanical study of medicinal plants used by people in Zegie Peninsula, North Western Ethiopia. J. Ethnobiol. Ethnomed., 3: 12.

77. Titanji, V.P.K., Zofou, D. and Ngemenya, M.N. (2008). The antimalarial potential of medicinal plants used for the treatment of malaria in Cameroonian folk medicine. AJTCAM., 5: 302-321.

78. Usman, H., Abdulrahman, F.I. and Usman, A. (2009). Qualitative phytochemical screening and in vitro antimicrobial effects of methanol stem bark extract of Ficus thonningii (Moraceae). AJTCAM., 6: 289-295.

79. Vitrac, X., Kussa, S., Decendit, A., Deffieux, G. and Menllon, J.M., (2004). Grapevine polyphenols and their biological effects, in: Ramawat, K.G. (Eds.), Biotechnology of Medicinal Plants, Vitalizers and Therapeutics, pp. $33-75$.

80. Von Gadow, A., Joubert, E. and Hansmann, C.F. (1997). Comparison of the antioxidant activities of rooibos tea (Aspalathus linearis) with green, oolong and black tea. Food Chem., 60: 73-77.

81. Watt, J.M. and Breyer-Branddwijk, G.M. (1962). The medicinal and poisonous plants of Southern and Eastern Africa, $2^{\text {nd }}$ ed. E. and S Livingstone Ltd, Edinburgh and London, pp. 773.

82. Wondimu,T., Arsi, A. and Ensemu, K. (2007). Ethnobotanical study of medicinal plants around 'Dheerera' town, Arsi Zone, Ethiopia. J. Ethnopharmacol., 112: 152-161.

83. Wu, N., Fu, K., Fu, Y.J., Zu, Y.G., Chang, F.R., Chen, Y.H., Liu, X.L, Kong, Y., Liu, W. and Gu, C.B. (2009). Antioxidant activities of extracts and main components of Pigeon pea (Cajanis cajan (L) Millsp) leaves. Molecules, 14: 1032-1043.

84. Ya, C., Gaffney, S.H., Lilley, T.H. and Haslam, E. (1988). Carbohydrate-polyphenol complexation pp. 553. In Hemingway, R.W and Karchesy (Eds.) Chemistry and Significance of Condensed Tannins. Plenum press, New York, N.Y

85. Youan, B.B.C., Coulibaly, S., Miezan, T.B., Doua, F. and Bamba, M. (1997). In vivo evaluation of sixteen plant extracts on mice inoculated with Trypanosoma brucei gambiense. B. World Health Organ., 75: 343-348.

86. Yu. F, L., Gapor, A. B.S. and Bender, W.S. (2005). Evidence for the protective effect of the polyunsaturated phytol side chain in tocotrienols on 17ß-estradiol epoxidation. Cancer Detect. Prev., 29: 383-388. 